\title{
Antioxidant activity, anti-proliferative activity, and amino acid profiles of ethanolic extracts of edible mushrooms
}

\author{
S. Panthong ${ }^{1,2}$, N. Boonsathorn ${ }^{2}$ and S. Chuchawankul ${ }^{3,4}$ \\ ${ }^{1}$ Graduate Program in Molecular Science of Medical Microbiology and \\ Immunology, Faculty of Allied Health Sciences, Chulalongkorn University, \\ Bangkok, Thailand \\ ${ }^{2}$ Medical Biotechnology Center, Medical Life Science Institute, \\ Department of Medical Sciences, Ministry of Public Health, Nonthaburi, Thailand \\ ${ }^{3}$ Department of Transfusion Medicine and Clinical Microbiology, \\ Faculty of Allied Health Sciences, Chulalongkorn University, Bangkok, Thailand \\ ${ }^{4}$ Innovation Center for Research and Development of Medical Diagnostic \\ Technology Project, Faculty of Allied Health Sciences, Chulalongkorn University, \\ Bangkok, Thailand
}

Corresponding author: S. Chuchawankul

E-mail: siriporn.ch@chula.ac.th

Genet. Mol. Res. 15 (4): gmr15048886

Received June 15, 2016

Accepted August 4, 2016

Published October 17, 2016

DOI http://dx.doi.org/10.4238/gmr15048886

Copyright $(2016$ The Authors. This is an open-access article distributed under the terms of the Creative Commons Attribution ShareAlike (CC BY-SA) 4.0 License.

ABSTRACT. Biological activities of various mushrooms have recently been discovered, particularly, immunomodulatory and antitumor activities. Herein, three edible mushrooms, Auricularia auricula-judae (AA), Pleurotus abalonus (PA) and Pleurotus sajor-caju (PS) extracted using Soxhlet ethanol extraction were evaluated for their antioxidative, anti-proliferative effects on leukemia cells. Using the Folin-Ciocalteau method and Trolox equivalent antioxidant capacity assay, phenolics 
and antioxidant activity were found in all sample mushrooms. Additionally, anti-proliferative activity of mushroom extracts against U937 leukemia cells was determined using a viability assay based on mitochondrial activity. PA $(0.5 \mathrm{mg} / \mathrm{mL})$ and AA $(0.25-0.5 \mathrm{mg} / \mathrm{mL})$ significantly reduced cell viability. Interestingly, PS caused a hormeticlike biphasic dose-response. Low doses $(0-0.25 \mathrm{mg} / \mathrm{L})$ of PS promoted cell proliferation up to $140 \%$ relative to control, whereas higher doses $(0.50$ $\mathrm{mg} / \mathrm{mL}$ ) inhibited cell proliferation. Against U937 cells, AA IC I0 $_{5}$ was 0.28 $\pm 0.04 \mathrm{mg} / \mathrm{mL}$, which was lower than PS or PA $\mathrm{IC}_{50}(0.45 \pm 0.01$ and 0.49 $\pm 0.001 \mathrm{mg} / \mathrm{mL}$, respectively). Furthermore, lactate dehydrogenase (LDH) leakage conferred cytotoxicity. PS and PA were not toxic to U937 cells at any tested concentration; AA $(0.50 \mathrm{mg} / \mathrm{mL})$ showed high LDH levels and caused 50\% cytotoxicity. Additionally, UPLC-HRMS data indicated several phytochemicals known to support functional activities as either antioxidant or anti-proliferative. Glutamic acid was uniquely found in ethanolic extracts of AA, and was considered an anti-cancer amino acid with potent anti-proliferative effects on U937 cells. Collectively, all mushroom extracts exhibited antioxidant effects, but their anti-proliferative effects were dose-dependent. Nevertheless, the AA extract, with highest potency, is a promising candidate for future applications.

Key words: Auricularia auricula-judae; Pleurotus abalonus; Pleurotus sajor-caju; Antioxidation; Anti-proliferation; Amino acid profiles

\section{INTRODUCTION}

Several kinds of medicinal and edible mushrooms are found in different locations worldwide. Mushrooms contain various compounds such as polysaccharides, proteins, fats, glycosides, phenols, flavonoids, carotenoids, and organic acids (Patel and Goyal, 2012). A number of studies showed that many mushrooms exhibit biological and medicinal properties, including antitumor activities, stimulatory effects on the immune cells (Maiti et al., 2008), and antioxidant activities (Kanagasabapathy et al., 2011; Umeo et al., 2015). Pleurotus sajorcaju (PS), Pleurotus abalonus (PA), and Auricularia auricula-judae (AA) are common edible mushrooms known to possess several chemical properties. Several lines of evidence demonstrated that polysaccharides from PS, PA and AA could inhibit proliferation of tumor cells. For example, water-soluble extracts from PS displayed antitumor activity against Sarcoma 180 (Zhuang et al., 1993). Ren et al. (2015) demonstrated that polysaccharides from PA exert potent antioxidant and anti-proliferative activities against LoVo cancer cells. Other researchers showed that the polysaccharide-peptide complex from the fruit bodies of PA induced anti-proliferative activities against human hepatoma (HepG2) and human breast cancer cells (MCF-7) (Li et al., 2012). Antiproliferative effects of AA on acinar cell carcinoma and sarcoma 180 cells were also described previously (Ma et al., 2010; Reza et al., 2011). However, the effect of these three mushrooms on human leukemic cells has not been investigated.

Acute myelocytic leukemia (AML) is a rare disease. It accounts for approximately $90 \%$ of all acute leukemias in adults, but is infrequent in children (Weinstein, 1999). The

Genetics and Molecular Research 15 (4): gmr15048886 
survival rate of AML patients is the lowest among all leukemia patients, and poor prognosis is observed in older patients. (Sandler and Ross, 1997; Redaelli et al., 2003). The highest incidence of AML is found in the United States, Australia, and western Europe (Jemal et al., 2002). Cancer statistics in 2016 reported that new cases and deaths of AML are the highest among other leukemias in the United States (Siegel et al., 2016). Chemotherapy can cause many sides effects such as diarrhea, nausea, and vomiting. Therefore, natural products such as edible mushrooms could be an alternative treatment to reduce those side effects. This study aimed to examine the antioxidant and anti-proliferative properties of ethanolic extracts from PS, PA and AA on AML. The human acute myelocytic leukemia U937 cell line was used as the experimental model. In addition, metabolic compounds and amino acids were analyzed by ultra-high performance liquid chromatography-high-resolution mass spectroscopy (UPLC-HRMS). This is the first report which detailed that edible mushrooms suppressed human leukemia in vitro.

\section{MATERIAL AND METHODS}

\section{Chemicals and reagents}

Gallic acid, 2,20-azinobis (3-ethylbenzoline 6-sulfonate) (ABTS), trolox (6-hydroxy-2,5,7,8-tetramethyl-chroman-2-carboxylic acid, a water-soluble tocopherol analogue), campthothecin (CAM), Folin-Ciocalteu phenolic reagent, and dimethyl sulfoxide (DMSO) were obtained from Sigma Chemicals Co. (St. Louis, MO, USA). Roswell Park Memorial Institute (RPMI)-1640 medium, fetal bovine serum (FBS), and phosphatebuffered saline (PBS) were purchased from Thermo Scientific HyClone (Logan, UT, USA). 3-(4,5-dimethylthiazol-2-yl)-5-(3-carboxymethoxyphenyl)-2-(4-sulfophenyl)-2H-tetrazolium (MTS), 3-(4,5-dimethylthiazol-2-yl)-2,5-diphenyltetrazolium bromide (MTT), and lactate dehydrogenase (LDH) were manufactured by Promega (Madison, WI, USA), Bio Basic Inc. (East Markham, ON, Canada) and Roche Diagnostics (Mannheim, Germany), respectively. All other basic reagents were of analytical grade.

\section{Extraction of PS, PA and AA fruit bodies}

Fruit bodies of PS were collected from a mushroom farm in Bangkok, Thailand. Fruit bodies of PA and AA were collected from local mushroom farms in Nonthaburi and Bangkok, Thailand. Morphological characteristics the mushrooms are shown in Figure 1. Mushrooms from all farms were cultivated and used for daily consumption. The fruiting bodies were dried and homogenized, mushroom powders $(20 \mathrm{~g}$ with $400 \mathrm{~mL}$ absolute ethanol) (Merck, Germany) were extracted using a Soxhlet extractor for $11 \mathrm{~h}$. After ethanol was removed with a rotary evaporator, crude extracts were dried in a freezedrier. The extraction yields of crude ethanolic extracts were calculated based on extracted materials using the formula below. The yields of ethanolic extracts of three mushrooms are shown in Table 1.

\footnotetext{
Yields (\%) $=[$ crude extract weight $(\mathrm{g}) /$ mushroom powder weight $(\mathrm{g})] \mathrm{x} 100 \quad$ (Equation 1)
} 
A

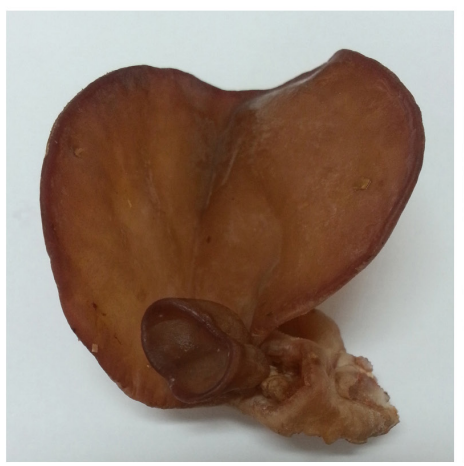

B

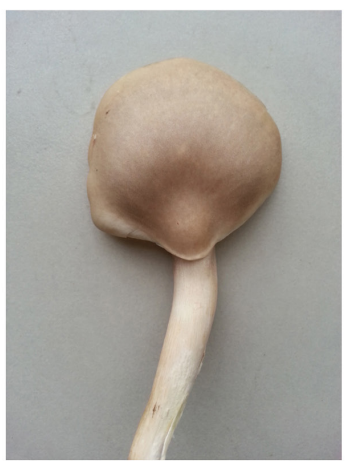

C

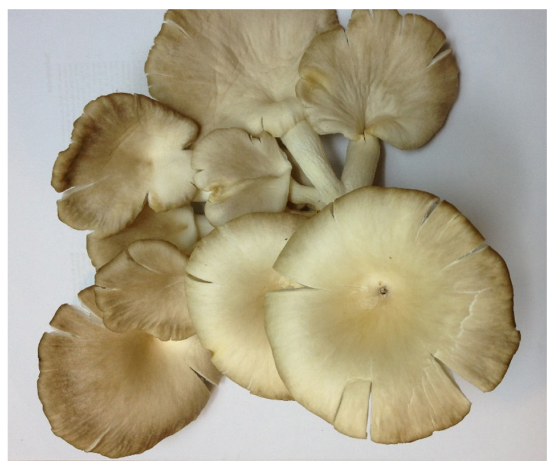

Figure 1. Morphological characteristic of Auriculata auricula-judae (A), Pleutorus abalonus (B) and Pleutorus sajor-caju $(\mathbf{C})$. Fruiting bodies of mushrooms were collected from the local farms in Thailand.

Table 1. Characteristics and yields of crude mushroom ethanolic extracts.

\begin{tabular}{l|l|c}
\hline Mushrooms & Colors of crude extracts & Yields (\% w/w) \\
\hline P. sajor-caju & Light yellow & 3.70 \\
\hline P. abalonus & Dark yellow & 6.40 \\
\hline A. auricula-judae & Pink & 2.40
\end{tabular}

\section{Measurement of phenolic content}

Total phenolic phytochemical content in all mushroom extracts was assessed by Folin-Ciocalteau's method, the standard method for determining antioxidant properties (Singleton et al., 1999). In the present study, total phenolic compounds from three edible mushrooms extracted by ethanol using Soxhlet extraction was expressed as millimolar gallic acid equivalent (GAE) per kilogram of dried fruit material.

\section{Trolox equivalent antioxidant capacity (TEAC) assay}

The antioxidant activities in all mushroom extracts were detected by TEAC (Pietta et al., 2000). Standard TEAC assay was used to assess the total radical scavenging ability of the compound of interest, which was measured by its ability to scavenge the stable ABTS radical in $6 \mathrm{~min}$. The result was given in relation to the activity of trolox, a water-soluble vitamin $\mathrm{E}$ analogue. Therefore, TEAC was the concentration of trolox with the same antioxidant activity as $1 \mathrm{mM}$ solution of the sample.

\section{Preparation of U937 cells}

The U937 cell line, a human cell line established from a diffuse histiocytic lymphoma (Clement and Lehmeyer, 1983), was a generous gift from Asst. Prof. Dr. Yaneenart Suwanwong (Department of Clinical Microscopy, Faculty of Allied Health Sciences, Chulalongkorn University, Bangkok, Thailand). Cells were maintained in RPMI-1640 supplemented with $10 \% \mathrm{FBS}$ at $37^{\circ} \mathrm{C}$ with $5 \% \mathrm{CO}_{2}$. 


\section{Determination of cell viability by MTS and MTT assays}

The mitochondrial dependent reduction of either MTS or MTT was determined colorimetrically in order to measure cell respiration, which was an indicator of cell viability (Mosmann, 1983; Goodwin et al., 1995). Briefly, U937 cells were seeded on 96-well plates (5 x $10^{3}$ cells/well), and incubated with each crude extract at various concentrations $(0.008-0.5 \mathrm{mg} /$ $\mathrm{mL}$ ) for $24-72 \mathrm{~h}$ at $37^{\circ} \mathrm{C}$ with $5 \% \mathrm{CO}_{2}$. CAM, a chemotherapeutic drug, served as the positive control of topoisomerase I inhibitor, and was used as the reference drug (Wu et al., 2010). DMSO was used as control solvent. Cell viability after PA and PS treatments was determined by MTS assay following the manufacturer instructions. After treatments, $20 \mu \mathrm{L}$ MTS solution was added to all wells. Plates were incubated at $37^{\circ} \mathrm{C}$ in $5 \% \mathrm{CO}_{2}$ for $4 \mathrm{~h}$. In the case of AA extract, as its natural color was found to interfere with the resulting color following MTS reaction, cell viability was determined by MTT assay instead. Supernatants were collected and absorbance was measured at 490 and $570 \mathrm{~nm}$ for MTS and MTT, respectively, using a Beckman Coulter DTX880 Multimode Detector (Fullerton, CA, USA). Percent cell viabilities and $\mathrm{IC}_{50}$ values were calculated as follows:

Cell viability $(\%$ of control $)=($ Absorbance sample $/$ Absorbance control $) \times 100 \quad($ Equation 2$)$

\section{Determination of cytotoxicity by LDH leakage}

Cytotoxicity induced by crude extracts was determined by LDH leakage into the culture medium. The activity of LDH in the medium was detected using the LDH assay kit commercially available from Roche Diagnostics (Mannheim, Germany). The percentages of cytotoxicity were calculated using the formula below:

Cytotoxicity $(\%)=[($ experimental value - low control $) /($ high control-low control $)] \times 100 \quad$ (Equation 3)

\section{UPLC-HRMS analysis}

All mushroom extracts were prepared and sent to the Institute of Chemical Technology, Hyderabad, India, for UPLC-HRMS analysis. The molecular formula of compounds was detected by HRMS via comparison between theoretical and observed mass. We also compared the mass values obtained with those found on existing databases such as the knapsack family databases (Afendi et al., 2012), the Metabolomics Workbench (http://www. metabolomicsworkbench.org), and the Human Metabolome Database (http://www.hmdb.ca). Unidentified metabolites were then matched using other general chemical databases such as Pubchem (http://pubchem.ncbi.nlm.nih.gov).

\section{Statistical analysis}

All values are reported as means \pm standard deviation, and one-way analysis of variance (ANOVA) was applied using the SAS program. The GraphPad Prism5 program was used to obtain the $\mathrm{IC}_{50}$ values. $\mathrm{P}$ values $<0.05$ were considered significant.

Genetics and Molecular Research 15 (4): gmr15048886 


\section{RESULTS}

\section{Total phenolic content and antioxidant activity of PS, PA, and AA ethanolic extracts}

Assays for total phenolic content and antioxidant activity of PS, PA and AA ethanolic extracts were carried out; results are presented in Figure 2.
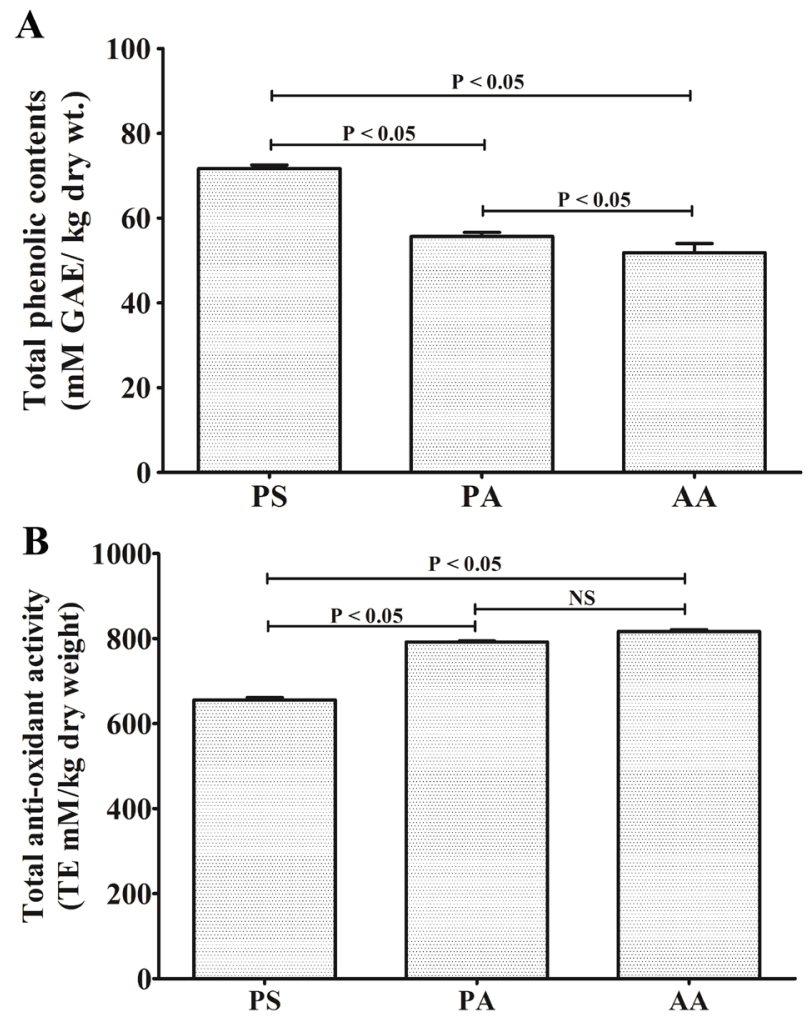

Figure 2. Total phenolic content (A) and antioxidant activity (B) of ethanolic extracts from PS, PA and AA. Data are reported as means $\pm \mathrm{SD}$. All experimental data were from three independent experiments. $\mathrm{P}$ values $<0.05$ were considered significant. $\mathrm{NS}=$ non-significant. $\mathrm{GAE}=$ gallic acid equivalent. $\mathrm{TE}=$ trolox equivalent.

The values of phenolic compounds found in PS, PA, and AA extracts were $71.77 \pm$ $0.83,55.70 \pm 0.93$, and $51.83 \pm 2.19 \mathrm{GAE} \mathrm{mM} / \mathrm{kg}$ dried weight, respectively (Figure $2 \mathrm{~A}$ ). Total phenolic content of PS extract was significantly greater than that of PA and AA. Among all three mushroom extracts, AA extract contained the lowest total phenolic content. On the contrary, AA extract demonstrated the highest antioxidant activity $(816.75 \pm 3.95 \mathrm{TE} \mathrm{mM} / \mathrm{kg}$ dried weight), followed by PA extract (792.25 $\pm 2.41 \mathrm{TE} \mathrm{mM} / \mathrm{kg}$ dried weight) and PS extract $(655.92 \pm 5.25 \mathrm{TE} \mathrm{mM} / \mathrm{kg}$ dried weight $)$, as shown in Figure 2B.

Genetics and Molecular Research 15 (4): gmr15048886 


\section{In vitro anti-proliferative effect of ethanolic extracts on U937 cells}

We evaluated the effects of varied concentrations of each mushroom ethanolic extract on U937 cell viability with different lengths of treatment $(24,48$, and $72 \mathrm{~h}$ ) via MTS and MTT assays. As shown in Figure 3A, we found that U937 cells treated with 0.031-0.5 mg/ $\mathrm{mL}$ PA extract for $24 \mathrm{~h}$ and $0.063-0.5 \mathrm{mg} / \mathrm{mL}$ for $48 \mathrm{~h}$ showed significant improvement in cell viability, which was dose-dependent. In contrast, a significant reduction of cell viability was observed after U937 cells were treated with $0.5 \mathrm{mg} / \mathrm{mL}$ PA extract for $72 \mathrm{~h}$; no change in cell viability with $0.008-0.25 \mathrm{mg} / \mathrm{mL}$ PA.
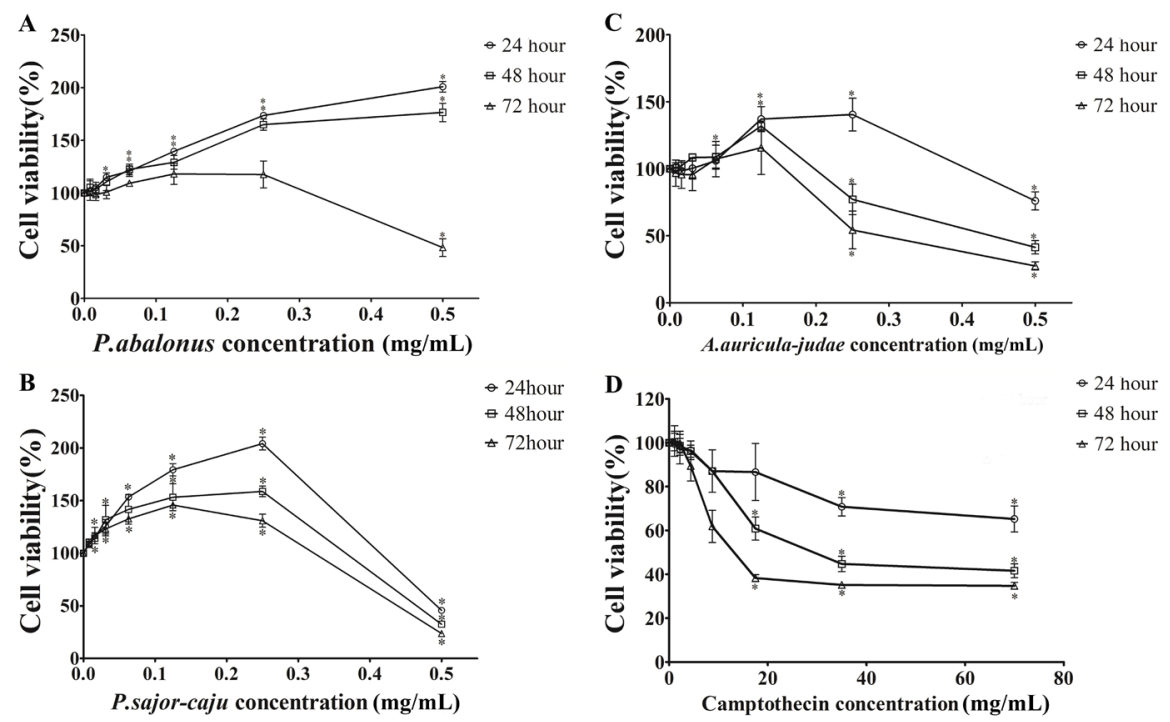

Figure 3. Effects of PS, PA, and AA ethanolic extracts on proliferation of U937 cells. After cell seeding, extracts $(0.008-0.5 \mathrm{mg} / \mathrm{mL})$ were added to the cell culture for 24,48 and $72 \mathrm{~h}$. Control cells were treated with $0.5 \%$ DMSO and camptothecin, a chemotherapeutic drug used as a positive control. Cell viability of PS and PA was determined by the MTS cell proliferation assay. Viability of AA treated cells were determined by MTT assay. Each data point represents the mean $\pm \mathrm{SD}$ of at least 3 independent experiments and each experiment was performed in triplicates. $\left({ }^{*} \mathrm{P}<0.05\right)$.

As shown in Figure 3B, treatment of U937 cells with PS extract at lower doses (ranging from 0.016 to $0.25 \mathrm{mg} / \mathrm{mL}$ ) resulted in a significant increase in cell viability. However, PS extract at $0.5 \mathrm{mg} / \mathrm{mL}$ significantly reduced cell viability by more than $50 \%$ at $24 \mathrm{~h}$, and its potency was increased in a time-dependent manner.

As shown in Figure 3C, increased cell viability was detected with at $0.125-0.25 \mathrm{mg} /$ $\mathrm{mL}$ AA extract for $24 \mathrm{~h}$, and $0.25 \mathrm{mg} / \mathrm{mL}$ for $48 \mathrm{~h}$. Treatment with at $0.5 \mathrm{mg} / \mathrm{mL}$ AA extract resulted in a significant drop in cell viability at all three time points; low concentration of AA extract treatment $(0.25 \mathrm{mg} / \mathrm{mL})$ was found to cause a significant decline of cell viability starting from $48 \mathrm{~h}$ of treatment.

CAM was used as a positive control for our cell viability assay, as shown in Figure $3 \mathrm{D}$. When it was used at an $\mathrm{ng} / \mathrm{mL}$ concentration range, a significant reduction in cell viability was observed in a time- and dose-dependent manner. Accordingly, as presented in Table 2, its 
$\mathrm{IC}_{50}$ value calculated from $72 \mathrm{~h}$ treatment was $11.45 \pm 2.12 \mathrm{ng} / \mathrm{mL}$. We found that the $\mathrm{IC}_{50}$ of AA was $0.28 \pm 0.04 \mathrm{mg} / \mathrm{mL}$, which was lower than that of PS $(0.45 \pm 0.01 \mathrm{mg} / \mathrm{mL})$ and PA $(0.49 \pm 0.001 \mathrm{mg} / \mathrm{mL})$.

\section{Table 2. $\mathrm{IC}_{50}$ values of mushroom ethanolic extracts and camptothecin}

\begin{tabular}{l|c}
\hline Mushrooms & IC $_{50}$ \\
\hline Auricularia auricula-judae & $0.28 \pm 0.04 \mathrm{mg} / \mathrm{mL}$ \\
\hline Pleutorus sajor-caju & $0.45 \pm 0.01 \mathrm{mg} / \mathrm{mL}$ \\
\hline Pleutorus abalonus & $0.49 \pm 0.001 \mathrm{mg} / \mathrm{mL}$ \\
\hline Camptothecin & $11.45 \pm 2.12 \mathrm{ng} / \mathrm{mL}$ \\
\hline
\end{tabular}

Each value represents the mean \pm SD of at least 3 replicates, and each experiment was independently performed 3 times. The GraphPad Prism5 program was used to obtain the $\mathrm{IC}_{50}$ values.

\section{In vitro cytotoxic effect of ethanolic extracts on $\mathrm{U} 937$}

Cytotoxic effect of mushroom extracts on U937 cells was determined by LDH assay. As shown in Figure 4, crude PS and PA ethanolic extracts had no effect on U937 cells at any of the tested concentrations as compared with untreated cells. On the contrary, AA extract at 0.25 and $0.5 \mathrm{mg} / \mathrm{mL}$ induced the cytotoxicity of $6.74 \pm 0.63 \%$ and $49.95 \pm 3.28 \%$, respectively.

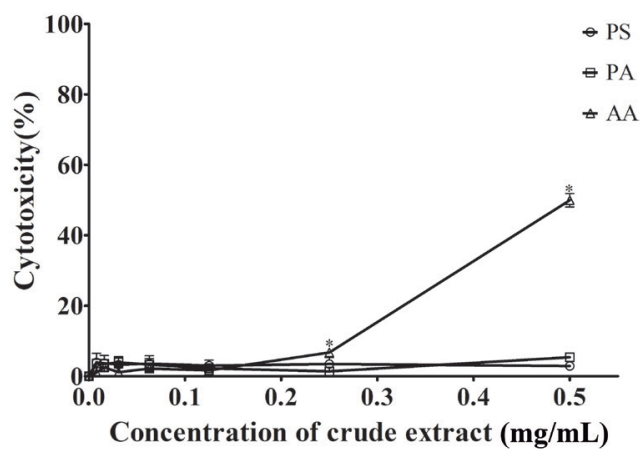

Figure 4. Cytotoxicity of PS, PA, and AA. Cell death was determined by the LDH release assay, which was carried out $24 \mathrm{~h}$ following PS, PA, and AA treatments. Data are reported as percentage of cytotoxicity. Each data point represents the mean $\pm \mathrm{SD}$ of at least 3 independent experiments, and each experiment was performed in triplicates. ${ }^{*} \mathrm{P}<0.05$.

\section{Metabolite profiling of PS, PA, and AA, as analysed by UPLC-HRMS}

Although qualitative screening of chemical compounds found in mushrooms have been conducted using different analytical techniques (Petrova et al., 2007; Kanagasabapathy et al., 2011; Lau et al., 2013; Mohd Jamil et al., 2013), our metabolite profile study of these three edible mushrooms was performed for the first time via UPLC-HRMS. Chromatograms for the positive modes of all mushroom extracts studied are compared in Figure 5. Several metabolites were found in the extracts, including phenols and derivatives, flavonoids, heterocyclic compounds, organic compounds, carbohydrates and sugar acids and derivatives, amino acids, nucleotides and nucleotides, benzenoids, lipids and fatty acids, steroids, and sterol lipids (Chuchawankul S, Panthong S and Boonsathorn N, unpublished results).

Genetics and Molecular Research 15 (4): gmr15048886 

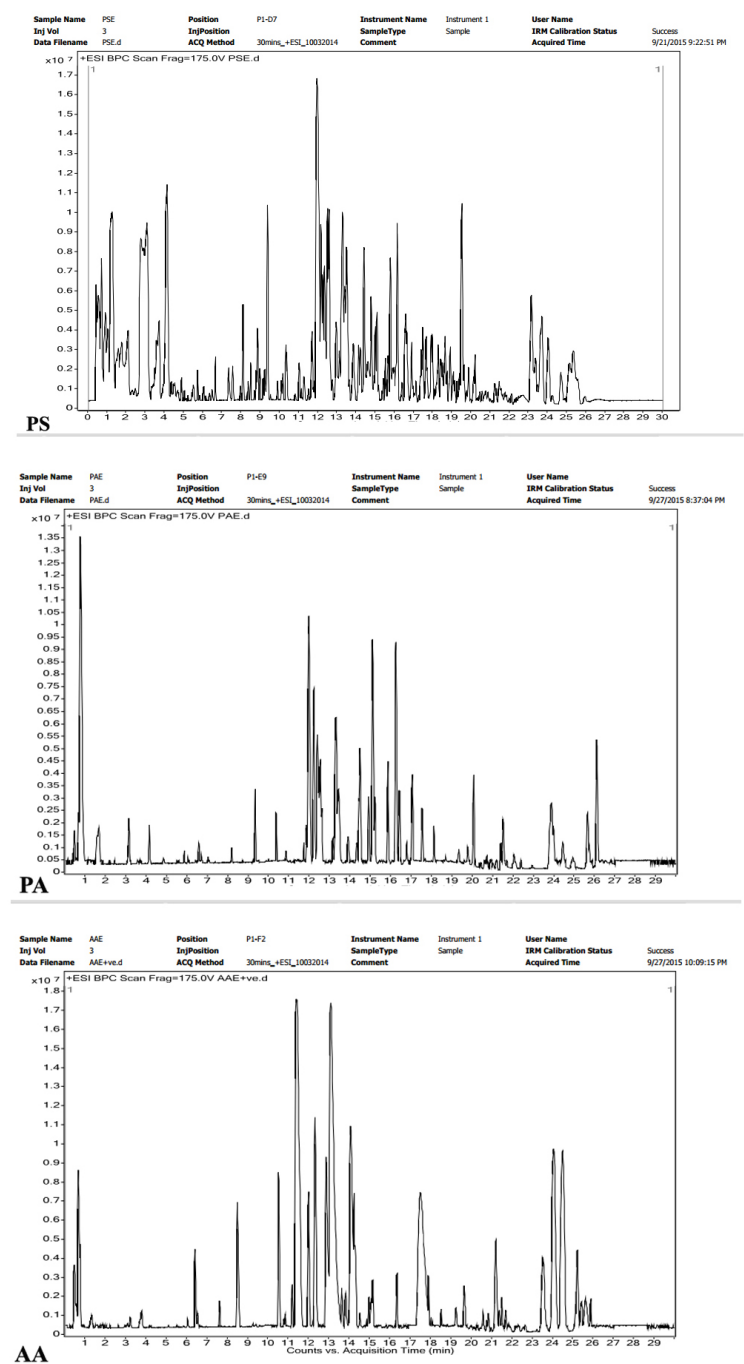

Figure 5. Full UPLC-HRMS spectrum scan of PS, PA, and AA ethanol extracts in the positive mode.

The phenols and flavonoids as well as their derivatives found in PS, PA and AA are shown in Tables 3 and 4.

Table 3. Phenol, phenol ethers and derivatives in PS, PA, and AA crude ethanolic extracts.

\begin{tabular}{|c|c|c|c|c|}
\hline RT (min) & Formula & Mass & Metabolite & Mushroom \\
\hline \multicolumn{5}{|l|}{ Phenol and derivatives } \\
\hline 1.324 & $\mathrm{C}_{9} \mathrm{H}_{13} \mathrm{NO}_{3}$ & 183.09 & Normetanephrine & AA \\
\hline $8.209,13.667,13.756$ & $\mathrm{C}_{18} \mathrm{H}_{29} \mathrm{NO}_{3}$ & 307.21 & Betaxolol & PA, PS \\
\hline 11.421 & $\mathrm{C}_{13} \mathrm{H}_{11} \mathrm{NO}_{3}$ & 229.07 & Fenamisal & AA \\
\hline 18.121 & $\mathrm{C}_{8} \mathrm{H}_{10} \mathrm{O}_{2}$ & 138.07 & 4-Hydroxyphenylethanol & PS \\
\hline \multicolumn{5}{|l|}{ Phenol ether } \\
\hline 8.129 & $\mathrm{C}_{18} \mathrm{H}_{29} \mathrm{NO}_{3}$ & 307.21 & 4-Hydroxypenbutolol & PS \\
\hline
\end{tabular}

Genetics and Molecular Research 15 (4): gmr15048886 
Table 4. Phenylpyruvic acid, phenylpropanoid and polyketides, flavonoids, terpenoids, and porphyrins in PS, PA and AA crude ethanolic extracts.

\begin{tabular}{|c|c|c|c|c|}
\hline RT (min) & Formula & Mass & Metabolite & Extract \\
\hline \multicolumn{5}{|c|}{ Phenylpyruvic acid and derivatives } \\
\hline 4.567 & $\mathrm{C}_{9} \mathrm{H}_{8} \mathrm{O}_{4}$ & 180.04 & 3-(4-Hydroxyphenyl) pyruvic acid & PS \\
\hline \multicolumn{5}{|c|}{ Phenylpropanoid and polyketides } \\
\hline 9.929 & $\mathrm{C}_{35} \mathrm{H}_{45} \mathrm{NO}_{10}$ & 639.31 & Protorifamycin I & PS \\
\hline 8.81 & $\mathrm{C}_{28} \mathrm{H}_{47} \mathrm{NO}_{8}$ & 525.32 & Pikromycin & PS \\
\hline 3.687 & $\mathrm{C}_{10} \mathrm{H}_{7} \mathrm{NO}_{3}$ & 189.04 & Alpha-cyano-3-hydroxycinnamic acid & PS \\
\hline 4.084 & $\mathrm{C}_{18} \mathrm{H}_{18} \mathrm{O}_{2}$ & 266.13 & Dienestrol & PA \\
\hline 11.421 & $\mathrm{C}_{9} \mathrm{H}_{10} \mathrm{FNO}_{2}$ & 183.07 & p-Fluorophenylalanine & AA \\
\hline \multicolumn{5}{|l|}{ Flavonoids } \\
\hline 0.708 & $\mathrm{C}_{21} \mathrm{H}_{24} \mathrm{O}_{10}$ & 436.13 & Phloridzin & PA \\
\hline \multicolumn{5}{|l|}{ Terpenoids } \\
\hline 9.4 & $\mathrm{C}_{32} \mathrm{H}_{40} \mathrm{O}_{9}$ & 568.27 & Swietenine & AA \\
\hline \multicolumn{5}{|l|}{ Porphyrins } \\
\hline 11.415 & $\mathrm{C}_{39} \mathrm{H}_{38} \mathrm{~N}_{4} \mathrm{O}_{12}$ & 754.23 & Heptacarboxylporphyrin III & AA \\
\hline
\end{tabular}

In terms of individual amino acids analyzed by UPLC-HRMS, we found essential and non-essential amino acids from three mushrooms, as demonstrated in Table 5. Eleven amino acids were found in all three ethanolic extracts, including alanine, arginine, asparagine, cysteine, glycine, isoleucine, lysine, phenylalanine, proline, tryptophan, and tyrosine. Interestingly, methionine, threonine and glutamic acid were only found in AA, but not in PA and PS. Moreover, serine was the only amino acid found in PA.

Table 5. Amino acid profiles of ethanolic extracts analyzed by UPLC-HRMS.

\begin{tabular}{l|c|c}
\hline \multirow{2}{*}{ Amino acid } & \multicolumn{2}{|c}{ Mushroom species } \\
\cline { 2 - 3 } & \multicolumn{1}{|c}{ Found } & Not found \\
\hline Alanine & PS, PA, AA & - \\
\hline Arginine & PS, PA, AA & PA \\
\hline Asparagine & PS, PA, AA & - \\
\hline Aspartic acid & PS, AA & PS, PA \\
\hline Cysteine & PS, PA, AA & PS \\
\hline Glutamic acid (Glu) & AA & PS, PA, AA \\
\hline Glutamine (Gln) & PA, AA & - \\
\hline Glycine & PS, PA, AA & AA \\
\hline Histidine* & PS, PA, AA & - \\
\hline Isoleucine* & PS, PA & PS, PA \\
\hline Leucine* & PS, PA, AA & - \\
\hline Lysine* & AA & - \\
\hline Methionine* & PS, PA, AA & PS, AA \\
\hline Phenylalanine* & PS, PA, AA & PS, PA \\
\hline Proline & PA & - \\
\hline Serine & AA & - \\
\hline Threonine* & PS, PA, AA & PS
\end{tabular}

*Essential amino acids.

\section{DISCUSSION}

Mushrooms are gradually gaining popularity due to their medicinal properties such as antitumor activities, stimulatory effects on the immune cells (Maiti et al., 2008) and 
antioxidant activities (Kanagasabapathy et al., 2011). Detrimental effects of oxidative stress can lead to many disorders in humans, which can be prevented by consumption of antioxidant substances (Ghosh et al., 2008; Ognjanović et al., 2008). It has long been known that natural antioxidants show fewer side effects than synthetic antioxidants. Edible mushrooms may be excellent sources of natural antioxidants and antitumor compounds.

In this study, we found that all mushroom extracts have phenolic content and demonstrated antioxidant activities. However, levels of total phenolic content found did not correlate with antioxidant activities, suggesting that non-phenolic compounds in mushrooms may also contribute to antioxidant properties. In particular, AA, with the lowest total phenolic content, was revealed to have the greatest antioxidant activity. However, we did not quantify the amount of flavonoids and other phytochemicals.

Based on the UPLC-HRMS data, a flavonoid, phloridzin, was detected in the PA extract. Phloridzin was previously found in apples and processed apple foods such as ciders and juice. This particular compound derived from apples was demonstrated to exhibit antioxidant activity (Boyer and Liu, 2004). Unique to the AA extracts, swietenine was also detected in this study. Swietenine found in the seed of the sky fruit, Swietenia macrophylla, has been reported to display anti-inflammatory, anti-mutagenicity, and antitumor activities (Dewanjee et al., 2009). Our study also detected tyrosol, or 4-hydroxyphenylethanol, in the PS extract. This specific constituent was quantitatively determined in five wide mushrooms from Greece, and was associated with free radical scavenging capacity, reducing power, and chelating ability (Kalogeropoulos et al., 2013).

The current investigation found betaxolol in both PS and PA extracts. Intriguingly, betaxolol, b-adrenergic antagonists (b-blockers), was revealed to induce antioxidative stress in rat retinal ganglion cells (Yu et al., 2007). Indeed, betaxolol is a common pharmaceutical active compounds found in the environment (Bosun, 2014). In this study, we found betaxolol in both PS and PA extracts from different farms. In addition, dienestrol, recognized as a phenolic environmental estrogen, was detected in PA extracts. Our results therefore suggested that the mushrooms were grown in an environment with a potential dienestrol contamination.

The anti-proliferative results (Figure 3B) suggested that PS extracts may either prevent or promote U937 cell growth depending on the dose applied, as it exhibited a biphasic effect on cell growth. This is a common phenomenon; more than a hundred antitumor agents enhance proliferation of human tumor cells at low doses and inhibit cell growth at high doses (Calabrese, 2005). Well-known antioxidant compounds include resveratrol, epigallocatechin gallate, curcumin, quercetin, allicin, capsaicin, carnosic acid, and sulforaphane have been classified as dietary hormetic compounds (Son et al., 2008; Calabrese et al., 2010; Vargas and Burd, 2010; Pietsch et al., 2011).

Our present data suggested that AA extract possess the highest potency with regard to anti-proliferative properties. Accordingly, previous studies have demonstrated that ethanolic extract from AA at $1 \mathrm{mg} / \mathrm{mL}$ showed an inhibitory activity against Sarcoma 180 cells (Reza et al., 2011; Reza et al., 2014). Mushrooms contain various compounds such as polysaccharides, proteins, fats, glycosides, phenols, flavonoids, carotenoids, organic acids, and minerals (Patel and Goyal, 2012; Yokota et al., 2016). Common active components in mushrooms such as polysaccharide, b-glucan, and protein-polysaccharide complex have been found to promote antitumor activities (Ooi and Liu, 2000). However, in terms of amino acids, methionine, threonine, and glutamic acid were found only in AA ethanolic extracts, but not in the ethanolic extracts of PA and PS. In addition, serine levels were undetectable in the ethanolic extracts

Genetics and Molecular Research 15 (4): gmr15048886 
of AA and PS, but were detected in those of PA. Nonetheless, we found that all the amino acids that were undetectable in the ethanolic extracts were present in the water extracts of the respective mushrooms. Furthermore, histidine, leucine, and serine, which were undetectable in AA ethanolic extracts, were present in the AA water extracts (Chuchawankul S, Panthong S and Boonsathorn N, unpublished results).

Glutamic acid, an essential amino acid, is the most abundant amino acid found in various mushroom species. Our results confirmed the presence of glutamic acid in AA ethanolic extracts. However, we did not quantify its exact concentration in this study. As expected, we found glutamic acid in the water extracts of all three mushrooms (Chuchawankul S, Panthong $\mathrm{S}$ and Boonsathorn $\mathrm{N}$, unpublished results).

All nine essential amino acids were previously found in the three mushrooms investigated in this study (Chirinang and Intarapichet, 2009; Li et al., 2012; Kadnikova et al., 2015), thus supporting the amino acid profiles detected by UPLC-HRMS. Interestingly, glutamic acid was found only in ethanolic extracts of AA, but not in that of PS and PA. The strong anti-proliferative effect of AA on U937 cells may be contributed by glutamic acid, as it was previously identified as an anticancer agent (Dutta et al., 2013).

In conclusion, this is the first study that not only demonstrated the in vitro antiproliferative activity of ethanolic extracts derived from fruiting bodies of edible mushrooms (PS, PA, and AA) on U937 cells, but also displayed their metabolite profile by UPLC-HRMS. Our metabolite profile data supported the hypothesis that mushroom extracts may exert antioxidant and anti-proliferative effects.

\section{Conflicts of interest}

The authors declare no conflict of interest.

\section{ACKNOWLEDGMENTS}

Research supported by the Ratchadaphiseksomphot Endowment Fund of Chulalongkorn University (\#CU-56-522-AS) and the 90th Anniversary of Chulalongkorn University Fund (Ratchadaphiseksomphot Endowment Fund, \#GCUGR1125582045M). We would like to thank the Medical Biotechnology Center, the Medical Life Science Institute, and the Chulalongkorn University Centenary Academic Development Project for their contribution of research instruments. We would like to express our gratitude to Assoc. Prof. Dr. Warin Sangkitikomol and Asst. Prof. Dr. Attakorn Palasuwan for providing reagents. We would like to offer special thanks to Dr. Atittaya Rocejanasaroj for her technical assistance. Moreover, the authors would like to thank Asst. Prof. Dr. Tewin Tencomnao for critical review of the manuscript.

\section{REFERENCES}

Afendi FM, Okada T, Yamazaki M, Hirai-Morita A, et al. (2012). KNApSAcK family databases: integrated metaboliteplant species databases for multifaceted plant research. Plant Cell Physiol. 53: e1.http://dx.doi.org/10.1093/pcp/ pcr165

Bosun B (2014). Environmental pharmacology - an overview. In: Pharmacology and therapeutics (Gowder SJT, ed.). InTech, Rijeka, 133-178.

Boyer J and Liu RH (2004). Apple phytochemicals and their health benefits. Nutr. J. 3: 5. http://dx.doi.org/10.1186/1475$\underline{2891-3-5}$

Genetics and Molecular Research 15 (4): gmr15048886 
Calabrese EJ (2005). Cancer biology and hormesis: human tumor cell lines commonly display hormetic (biphasic) dose responses. Crit. Rev. Toxicol. 35: 463-582. http://dx.doi.org/10.1080/10408440591034502

Calabrese EJ, Mattson MP and Calabrese V (2010). Resveratrol commonly displays hormesis: occurrence and biomedical significance. Hum. Exp. Toxicol. 29: 980-1015. http://dx.doi.org/10.1177/0960327110383625

Chirinang Pand Intarapichet KO (2009). Amino acids and antioxidant properties of the oyster mushrooms Pleurotus ostrestus and Pleurotus sajor-caju. Sci. Asia 35: 326-331. http://dx.doi.org/10.2306/scienceasia1513-1874.2009.35.326

Clement LT and Lehmeyer JE (1983). Regulation of the growth and differentiation of a human monocytic cell line by lymphokines. I. Induction of superoxide anion production and chemiluminescence. J. Immunol. 130: 2763-2766.

Dutta S, Ray S and Nagarajan K (2013). Glutamic acid as anticancer agent: An overview. Saudi Pharm. J. 21: 337-343. http://dx.doi.org/10.1016/j.jsps.2012.12.007

Dewanjee S, Maiti A, Das AK, Mandal SC, et al. (2009). Swietenine: a potential oral hypoglycemic from Swietenia macrophylla seed. Fitoterapia 80: 249-251.http://dx.doi.org/10.1016/j.fitote.2009.02.004

Goodwin CJ, Holt SJ, Downes S and Marshall NJ (1995). Microculture tetrazolium assays: a comparison between two new tetrazolium salts, XTT and MTS. J. Immunol. Methods 179: 95-103.http://dx.doi.org/10.1016/0022-1759(94)00277-4

Ghosh T, Maity KT, Sengupta P, Dash KD, et al. (2008). Antidiabetic and in vivo antioxidant activity of ethanolic extract of Bacopa monnieri Linn. aerial parts: a possible mechanism of action. Iran. J. Pharm. Res. 7: 61-68.

Jemal A, Thomas A, Murray T and Thun M (2002). Cancer statistics, 2002. CA Cancer J. Clin. 52: 23-47. http://dx.doi. org/10.3322/canjclin.52.1.23

Kadnikova IA, Costa R, Kalenik TK, Guruleva ON, et al. (2015). Chemical composition and nutritional value of the mushroom Auricularia auricula-judae. J. Food Nutr. Res. 3: 478-482.

Kanagasabapathy G, Malek SNA, Kuppusamy UR and Vikineswary S (2011). Chemical composition and antioxidant properties of extracts of fresh fruiting bodies of Pleurotus sajor-caju (Fr.) Singer. J. Agric. Food Chem. 59: 26182626. http://dx.doi.org/10.1021/jf104133g

Kalogeropoulos N, Yanni AE, Koutrotsios G and Aloupi M (2013). Bioactive microconstituents and antioxidant properties of wild edible mushrooms from the island of Lesvos, Greece. Food Chem. Toxicol. 55: 378-385. http://dx.doi. $\underline{\text { org } / 10.1016 / j . f c t .2013 .01 .010}$

Lau CC, Abdullah N and Shuib AS (2013). Novel angiotensin I-converting enzyme inhibitory peptides derived from an edible mushroom, Pleurotus cystidiosus O.K. Miller identified by LC-MS/MS. BMC Complement. Altern. Med. 13: 313. http://dx.doi.org/10.1186/1472-6882-13-313

Li N, Li L, Fang JC, Wong JH, et al. (2012). Isolation and identification of a novel polysaccharide-peptide complex with antioxidant, anti-proliferative and hypoglycaemic activities from the abalone mushroom. Biosci. Rep. 32: 221-228. http://dx.doi.org/10.1042/BSR20110012

Ma ZC, Wang JG, Zhang L, Zhang YF, et al. (2010). Evaluation of water soluble b-D-glucan from Auricularia auricularjudae as potential anti-tumor agent. Carbohydr. Polym. 80: 977-983. http://dx.doi.org/10.1016/j.carbpol.2010.01.015

Maiti S, Bhutia SK, Mallick SK, Kumar A, et al. (2008). Antiproliferative and immunostimulatory protein fraction from edible mushrooms. Environ. Toxicol. Pharmacol. 26: 187-191.http://dx.doi.org/10.1016/j.etap.2008.03.009

Mohd Jamil NA, Rahmad N, Mohd Nor Rashid N, Mohd Yusoff MHY, et al. (2013). LCMS-QTOF determination of lentinan-like b-D-glucan content isolated by hot water and alkaline solution from tiger's milk mushroom, termite mushroom, and selected local market mushrooms. J. Mycol. 2013: 718963.

Mosmann T (1983). Rapid colorimetric assay for cellular growth and survival: application to proliferation and cytotoxicity assays. J. Immunol. Methods 65: 55-63.http://dx.doi.org/10.1016/0022-1759(83)90303-4

Ognjanović BI, Marković SD, Pavlović SZ, Zikić RV, et al. (2008). Effect of chronic cadmium exposure on antioxidant defense system in some tissues of rats: protective effect of selenium. Physiol. Res. 57: 403-411.

Ooi VE and Liu F (2000). Immunomodulation and anti-cancer activity of polysaccharide-protein complexes. Curr. Med. Chem. 7: 715-729. http://dx.doi.org/10.2174/0929867003374705

Patel S and Goyal A (2012). Recent developments in mushrooms as anticancer therapeutics: a review. 3 Biotech 2: 1-15.

Petrova A, Alipieva K, Kostadinova E, Antonova D, et al. (2007). GC-MS studies of the chemical composition of two inedible mushrooms of the genus Agaricus. Chem. Cent. J. 1:33.http://dx.doi.org/10.1186/1752-153X-1-33

Pietsch K, Saul N, Chakrabarti S, Stürzenbaum SR, et al. (2011). Hormetins, antioxidants and prooxidants: defining quercetin-, caffeic acid- and rosmarinic acid-mediated life extension in C. elegans. Biogerontology 12: 329-347. http://dx.doi.org/10.1007/s10522-011-9334-7

Pietta P, Simonetti P, Gardana C and Mauri P (2000). Trolox equivalent antioxidant capacity (TEAC) of Ginkgo biloba flavonol and Camellia sinensis catechin metabolites. J. Pharm. Biomed. Anal. 23: 223-226.http://dx.doi.org/10.1016/ $\underline{\mathrm{S} 0731-7085(00) 00272-7}$

Redaelli A, Lee JM, Stephens JM and Pashos CL (2003). Epidemiology and clinical burden of acute myeloid leukemia. Expert Rev. Anticancer Ther. 3: 695-710. http://dx.doi.org/10.1586/14737140.3.5.695

Genetics and Molecular Research 15 (4): gmr15048886 
Ren D, Jiao Y, Yang X, Yuan L, et al. (2015). Antioxidant and antitumor effects of polysaccharides from the fungus Pleurotus abalonus. Chem. Biol. Interact. 237: 166-174.http://dx.doi.org/10.1016/j.cbi.2015.06.017

Reza A, Choi MJ, Damte D, Jo WS, et al. (2011). Comparative antitumor activity of different solvent fractions from an Auricularia auricula-judae ethanol extract in P388D1 and sarcoma 180 cells. Toxicol. Res. 27: 77-83. http://dx.doi. org/10.5487/TR.2011.27.2.077

Reza MA, Hossain MA, Lee SJ, Yohannes SB, et al. (2014). Dichlormethane extract of the jelly ear mushroom Auricularia auricula-judae (higher Basidiomycetes) inhibits tumor cell growth in vitro. Int. J. Med. Mushrooms 16: 37-47. http:// dx.doi.org/10.1615/IntJMedMushr.v16.i1.40

Sandler DP and Ross JA (1997). Epidemiology of acute leukemia in children and adults. Semin. Oncol. 24: 3-16.

Siegel RL, Miller KD and Jemal A (2016). Cancer statistics, 2016. CA Cancer J. Clin. 66: 7-30. http://dx.doi.org/10.3322/ caac. 21254

Singleton VL, Orthofer R and Lamuela-Raventos RM (1999). Analysis of total phenols and other oxidation substrates and antioxidants by means of folin-ciocalteu reagent. Methods Enzymol. 299: 152-178. http://dx.doi.org/10.1016/ S0076-6879(99)99017-1

Son TG, Camandola S and Mattson MP (2008). Hormetic dietary phytochemicals. Neuromolecular Med. 10: 236-246. http://dx.doi.org/10.1007/s12017-008-8037-y

Umeo SH, Souza GPN, Rapachi PM, Garcia DM, et al. (2015). Screening of basidiomycetes in submerged cultivation based on antioxidant activity. Genet. Mol. Res. 14: 9907-9914.http://dx.doi.org/10.4238/2015.August.19.25

Vargas AJ and Burd R (2010). Hormesis and synergy: pathways and mechanisms of quercetin in cancer prevention and management. Nutr. Rev. 68: 418-428. http://dx.doi.org/10.1111/j.1753-4887.2010.00301.x

Weinstein HJ (1999). Acute myeloid leukemia. In: Childhood leukemias (Pui CH, ed.) Cambridge University Press, United Kingdom, 322-335.

Wu N, Wu XW, Agama K, Pommier Y, et al. (2010). A novel DNA topoisomerase I inhibitor with different mechanism from camptothecin induces G2/M phase cell cycle arrest to K562 cells. Biochemistry 49: 10131-10136. http://dx.doi. org $/ 10.1021 / \mathrm{bi} 1009419$

Yokota ME, Frison PS, Marcante RC, Jorge LF, et al. (2016). Iron translocation in Pleurotus ostreatus basidiocarps: production, bioavailability, and antioxidant activity. Genet. Mol. Res. 15: gmr.15017888

Yu ZK, Chen YN, Aihara M, Mao W, et al. (2007). Effects of beta-adrenergic receptor antagonists on oxidative stress in purified rat retinal ganglion cells. Mol. Vis. 13: 833-839.

Zhuang C, Mizuno T, Shimada A, Ito H, et al. (1993). Antitumor protein-containing polysaccharides from a Chinese mushroom Fengweigu or Houbitake, Pleurotus sajor-caju (Fr.) Sings. Biosci. Biotechnol. Biochem. 57: 901-906. http://dx.doi.org/10.1271/bbb.57.901

Genetics and Molecular Research 15 (4): gmr15048886 